\author{
Anna Wojcieszczak \\ Uniwersytet Jagielloński \\ (D) https://orcid.org/0000-0001-7482-801X \\ https://doi.org/10.15633/9788374386753.11
}

\title{
Mediacja rówieśnicza jako forma socjalizacji prawnej dzieci i młodzieży
}

\section{Zastosowanie mediacji w rozwiązywaniu konfliktów zaistniałych w szkole}

W środowisku szkolnym na co dzień można zaobserwować różnorodne konflikty, do których dochodzi pomiędzy członkami tej zbiorowości - uczniami, rodzicami i nauczycielami. U podstaw tych konfliktów najczęściej leżą problemy komunikacyjne i brak wzajemnego zrozumienia. Biorąc pod uwagę wiek i stopień rozwoju emocjonalnego uczniów oraz specyficzną strukturę administracyjną i organizacyjną szkoły, do rozwiązywania konfliktów konieczne jest zastosowanie adekwatnych metod. Na szczególną uwagę zasługują konflikty rówieśnicze, do których rozwiązywania coraz częściej wykorzystywane są techniki mediacyjne. Szkoła w znaczący sposób kształtuje osobowość dziecka. Wychowanie to świadomy proces oddziaływania wychowawcy na wychowanka w celu wypracowania u niego pożądanych cech, zachowań i - jeśli występuje taka potrzeba - zmian w jego osobowości ${ }^{1}$. Prócz edukacji szkoła przygotowuje także młodego człowieka do aktywnego i świadomego uczestnictwa w życiu społecznym. Zazwyczaj to właśnie w szkole uczniowie po raz pierwszy mają styczność z obowiązującymi normami i zasadami współżycia społecznego ${ }^{2}$. Szkoła to miejsce, które pełni bardzo ważną

1 Por. K. Wojtanowicz, Mediacje rówieśnicze jako metoda wychowawcza, „Studia Socialia Cracoviensia „8 (2016) nr 2 (15), s. 145-155.

2 Por. A. Wojcieszczak, Mediacja rówieśnicza jako metoda kształtowania postaw prospotecznych iprzeciwdziatania agresji wśród dzieci imłodzieży, w: Bezpieczne miasto - wposzukiwaniu wiedzy przydatnej praktykom, red. J. Czapska, P. Mączyński, K. Struzińska, Kraków 2017, s. 221-236. 
rolę w socjalizacji dzieci i młodzieży ${ }^{3}$, w tym również socjalizacji prawnej. Socjalizacja prawna jest to „proces przejmowania, czyli stopniowej asymilacji i osobistej reorganizacji przez podmiot - w ramach jego własnego systemu wyobrażeń i wiedzy - elementów współtworzących system prawny panujący w społeczeństwie”4; jest „procesem, w którym jednostki nabywają postawy, poglądy wobec prawa, prawodawcy oraz instytucji prawnych" . Edukacja dzieci i młodzieży w zakresie mediacji rówieśniczej może stanowić przejaw socjalizacji prawnej. Mediacja rówieśnicza odwołuje się do przewidzianych w prawie zasad, bazuje na stworzonych przez Rzecznika Praw Dziecka standardach ${ }^{6}$, realizuje koncepcję sprawiedliwości naprawczej, ale także może posłużyć jako skuteczne narzędzie bezprzemocowego rozwiązywania konfliktów między uczniami. Edukacja w zakresie alternatywnych metod rozwiązywania sporów może przyczynić się do zredukowania negatywnych zachowań i wykształcenia właściwych postaw społecznych - zachęcając do dialogu, wzajemnego zrozumienia i aktywnego poszukiwania polubownych rozwiązań.

W ostatnich latach agresywne zachowania wśród młodzieży uległy zmianie i coraz częściej zaczynają mieć związek z dynamicznym rozwojem i upowszechnieniem dostępu do nowych technologii - pojawia się tzw. cyberprzemoc (cyberbulling), polegająca na rozpowszechnianiu nieprawdziwych treści i materiałów mających skompromitować kogoś na portalach internetowych, nękaniu wiadomościami na komunikatorach i SMS-ami lub też podszywaniu się pod kogoś w Internecie ${ }^{7}$. Mając na uwadze wspomnianą ewolucję zachowań konfliktogennych i agresywnych, należy zastanowić się nad adekwatnymi metodami zapobiegania, przeciwdziałania i kształtowania prospołecznych postaw zmierzających do stworzenia przyjaznego środowiska sprzyjającego nauce i radzeniu sobie z konfliktami w konstruktywny sposób. Mediacja rówieśnicza może być świetnym narzędziem, w oparciu o które

3 Por. B. Godyla, Socjalizacyjny wptyw szkoty na rozwój społeczny dziecka, „EduX.pl”, http://www. edukacja.edux.pl/p-617-socjalizacyjny-wplyw-szkoly-na-rozwoj.php (dostęp: 21.07.2021).

4 M. Borucka-Arctowa, G. Skąpska, Teoretyczne problemy socjalizacjiprawnej, w: Socjalizacjaprawna, red. M. Borucka-Arctowa, Ch. Kourilsky, Warszawa 1993, s. 11-27.

5 A.R. Piquero, J. Fagan, P.E. Mulvey, L. Steinberg, C. Odgers, Developmental Trajectories of Legal Socialization Among Serious Adolescent Offenders, „The Journal of Criminal Law and Criminology" (2005) no. 96 (1), s. 267-298.

6 Por.http://brpd.gov.pl/sites/default/files/standardy_mediacji_rowiesniczej_i_szkolnej_w_szkolach_o.pdf.

7 Por. A. Borkowska, J. Szymańska, M. Witkowska, Przeciwdziałanie agresji i przemocy w szkole. Poradnik dla nauczycieli, Warszawa 2012, http://www.ore.edu.pl. 
samorządy i placówki oświatowe coraz częściej tworzą i wdrażają programy edukacyjno-profilaktyczne, które wprowadzają do programu nauczania podstawy prawa i wiedzy o społeczeństwie oraz popularyzują ideę sprawiedliwości naprawczej w zapobieganiu przemocy rówieśniczej w szkole ${ }^{8}$.

Mediacja to próba doprowadzenia do ugodowego, zadowalającego dla obu stron porozumienia poprzez moderowane przez neutralną i bezstronną osobę trzecią dobrowolne negocjacje pomiędzy skonfliktowanymi stronami. (Społeczna Rada ds. Alternatywnych Metod Rozwiązywania Konfliktów i Sporów przy Ministrze Sprawiedliwości). Mediacja stanowi swoistą innowację w prawie, a jej wdrażaniu wciąż jeszcze towarzyszy bariera związana $\mathrm{z}$ brakiem dostatecznej wiedzy ${ }^{9}$, dlatego tak istotna w tym zakresie jest edukacja od najmłodszych lat. Po właściwym wdrożeniu i ujęciu tej metody w statucie szkoły mediację można wykorzystać jako jeden ze sposobów bezprzemocowego rozwiązywania sporów, do których dochodzi pomiędzy uczniami - metoda ta sprzyja aktywizowaniu uczniów i kształtowaniu postawy wzajemnego zrozumienia i empatii. Mediacja rówieśnicza to metoda rozwiązywania konfliktów zaistniałych w środowisku szkolnym (wśród dzieci i młodzieży na terenie szkoły, placówki opiekuńczo-wychowawczej lub resocjalizacyjnej) z pomocą bezstronnego mediatora - zaufanego i powszechnie akceptowanego rówieśnika - pod opieką pedagoga szkolnego lub innego nauczyciela (superwizja). Zadaniem mediatora rówieśniczego jest wsparcie stron w dojściu do porozumienia, a sama mediacja koncentruje się na rozwiązaniu problemu i podtrzymaniu pomiędzy skonfliktowanymi uczniami dobrej relacji - bez konieczności wskazania winnego. Dobrze przeprowadzona mediacja daje szansę na wypracowanie ugody zadowalającej obie strony oraz takiej, która będzie przez nie w przyszłości przestrzegana. Uczniowie biorą na siebie odpowiedzialność za rozwiązanie sporu, mają możliwość przedstawienia drugiej stronie swoich odczuć i interpretacji jej zachowania. W rezultacie pozwala to na kształtowanie wśród młodzieży postaw empatycznych i spełnia funkcję sprawiedliwości naprawczej - sprawca i pokrzywdzony uczeń mają poczucie, że zostali wysłuchani, a także mają możliwość pojednać się i zapewnić, że zaistniała sytuacja już się nie powtórzy. Mediacja kończy się pisemnym utrwaleniem rezultatów poprzez spisanie symbolicznej

8 Por. W. Klaus, Wykorzystanie sprawiedliwości naprawczej w zapobieganiu przemocy rówieśniczej wszkole, w: Mediacja, red. L Mazowiecka, Warszawa 2009, s. 339.

9 Por. J. Czapska, M. Szeląg-Dylwski, Innowacja przez prawo, czyli rzecz o mediacji i zaufaniu, w: Mediacje w prawie, red. J. Czapska, M. Szeląg-Dylewski, Kraków 2014, s. 11. 
ugody, która może zawierać, między innymi, przeprosiny za nieprzyjazne zachowanie, ofertę rekompensaty strat i wyrządzonych szkód oraz deklarację niedoprowadzania do podobnych sytuacji i zdarzeń konfliktowych w przyszłości. W tym miejscu należy podkreślić prospektywną orientację tej metody, która skłania uczestników do szerszego spojrzenia na zaistniały problem i refleksji nad tym, jak uniknąć podobnych zdarzeń w przyszłości. Nad całym procesem czuwa odpowiednio do tego przygotowany i cieszący się uznaniem uczniów nauczyciel, który obserwuje przebieg spotkania, a w sytuacjach kryzysowych może zainterweniować i wesprzeć mediatora rówieśniczego - nie powinien on jednak zbyt często ingerować w przebieg spotkania, bowiem filarem mediacji rówieśniczej jest oddanie, w dobrej wierze, sprawiedliwości w ręce rówieśników ${ }^{10}$. Ze względu na wiek stron i specyfikę konfliktów szkolnych często stosuje się model komediacyjny, mediacja prowadzona jest przez dwóch uczniów-mediatorów. Taka metoda ma na celu nie tylko zapewnienie komfortu i bezpieczeństwa pracy młodym mediatorom, ale też pozwala na obiektywne i bezstronne podejście do omawianej sprawy. Mediacja rówieśnicza jest mniej sformalizowaną i nieco bardziej przyjazną dla uczniów odmianą standardowej mediacji, czerpie jednak z jej mechanizmów i opiera się na jej podstawowych zasadach.

Uczestnictwo uczniów w mediacji jest dobrowolne, oznacza to, że mediacja odbędzie się tylko wówczas, gdy skonfliktowane strony będą chciały ze sobą porozmawiać i dojść do porozumienia. Nikt, nawet nauczyciel, nie może zmusić uczniów do mediowania, decyzja o przystąpieniu do mediacji musi pochodzić od stron, które chcą ze sobą porozmawiać i w ten sposób poszukać możliwej płaszczyzny porozumienia. Bardzo ważne jest, aby uczniowie darzyli zaufaniem zarówno nauczycieli zaangażowanych w projekt, jak i uczniów-mediatorów. Dlatego też często stosuje się różne, demokratyczne formy wyboru uczniów-mediatorów, pozwalając już na wstępnym etapie przenieść odpowiedzialność za tę decyzję na uczniów, okazując im zrozumienie i zaufanie. Ze względu na zamknięty charakter społeczności szkolnej duży nacisk należy położyć na przestrzeganie zasady poufności, według której treść mediacji jest tajemnicą i nie powinna zostać ujawniona. Zapewnienie dyskrecji jest gwarantem zaufania i otwartości na dialog skonfliktowanych uczniów, którzy często w trakcie sesji mediacyjnej będą poruszać 
delikatne dla siebie kwestie. Dąży się do takiego przeprowadzenia mediacji, aby zaspokojone zostały potrzeby obu stron (win-win), oraz aby zrealizowana została funkcja edukacyjna ${ }^{11}$. Mediatorem rówieśniczym powinien być uczeń, który - po ukończeniu właściwych szkoleń przygotowawczych daje stronom poczucie bezpieczeństwa i jest w miarę możliwości bezstronny i neutralny. Tylko wtedy uczniowie-strony zaakceptują mediatora i będą bez obaw podejmowali próbę polubownego rozwiązania konfliktu. Mediator rówieśniczy powinien cieszyć się zaufaniem społeczności szkolnej i być gwarantem przestrzegania podstawowych zasad mediacji. Powodzenie projektu mediacyjnego w znacznym stopniu zależy od tego, jakie osoby będą jego przedstawicielami w szkole - czy będą akceptowane przez innych uczniów. W dotychczasowej praktyce nie wypracowano jednolitych kryteriów dotyczących metod wyłaniania mediatorów rówieśniczych. Młodzi ludzie pełniący tę funkcję są zazwyczaj wyłaniani z grona uczniów przez nauczycieli lub pedagogów szkolnych, często także przeprowadza się pośród młodzieży ankiety, w których rówieśnicy wskazują kolegów i koleżanki, którzy ich zdaniem mogliby pełnić tę funkcję i którzy w ich mniemaniu sprostają stawianym mediatorowi wymaganiom. Wspomniane ankiety pomagają $\mathrm{w} w \mathrm{w}-$ typowaniu mediatorów, którzy cieszą się zaufaniem i uznaniem grupy rówieśniczej. Mediatorem w sporach szkolnych może być uczeń, który: cieszy się zaufaniem kolegów i nauczycieli, jest autorytetem dla rówieśników, reprezentuje wartości respektowane przez szkołę, odbył podstawowe szkolenie z zakresu mediacji, posiada umiejętności komunikacyjne, swoją postawą zachęca i motywuje innych do działania, wykazuje własną inicjatywę, stale poszerza swoją wiedzę w zakresie mediacji, a także posiada odpowiednie predyspozycje osobowościowe - na przykład otwartość i szacunek do innych ludzi. Mediacja to forma zrozumienia konfliktu, nazwania go i spojrzenia na niego jak na problem, który można rozwiązać, a nie jak na walkę z drugim człowiekiem $^{12}$. W realiach szkolnych może być ona doskonałą okazją do zmiany i kształtowania postaw uczniów - w przyszłości będą mogli wykorzystać zdobytą w ten sposób wiedzę i umiejętności w kontaktach z rówieśnikami, w życiu rodzinnym i zawodowym. Należy także zaznaczyć, że zwiększenie

1 Rebis, Poznań 2011, s. 379.

12 wiązywania konfliktów w szkole, w: Mediacje ponad podziałami, red. M. Tabernacka, Wrocław 2013, s. 71-83 (e-Monografie, 41). 
świadomości uczniów w zakresie ugodowego rozwiązywania sporów może mieć pozytywny wpływ na prawidłowe funkcjonowanie szkoły jako zinstytucjonalizowanej zbiorowości uczniów, nauczycieli i rodziców. Popularyzacja programu mediacji rówieśniczej objęta została honorowym patronatem Rzecznika Praw Dziecka. Program „Mediacja rówieśnicza w szkole metodą przeciwdziałania agresji i niedostosowaniu społecznemu młodzieży” jest kontynuacją działań prowadzonych dotychczas przez Sąd Okręgowy w Lublinie w oparciu o doświadczenia z pilotażowego programu mediacyjnego Rzecznika Praw Dziecka ${ }^{13}$. W ostatnich latach w ramach poszerzania wiedzy obywateli o alternatywnych metodach rozwiązywania konfliktów realizowano także inne, specjalne projekty, takie jak „COOLtura konfliktu” czy „Szkoła bez przemocy”, które pomogły placówkom oświatowo-wychowawczym stworzyć indywidualne programy dotyczące rozwiązywania konfliktów uczniowskich ${ }^{14}$. Ponadto wiele samorządów i władz miejskich w całej Polsce zdecydowało się wdrożyć programy mediacji rówieśniczej w lokalnych szkołach. Przykładem działania miejskiego, w ramach którego zrealizowano projekt mediacji rówieśniczej, jest program „Bezpieczny Kraków"15. W ramach programu wyszczególniono cel szczegółowy pod nazwą „Bezpieczna Szkoła”, który koncentrował się na działaniach związanych z poprawą bezpieczeństwa w szkole, w tym także z edukacją dzieci i młodzieży w zakresie mediacji. Stosowanie mediacji rówieśniczej w szkole pozwala dostrzec jej zalety, ale i niedoskonałości. Wśród zalet mediacji rówieśniczej wymienić należy: (1) wzrost świadomości uczniów, nauczycieli, rodziców na temat metod rozwiązywania konfliktów; (2) nabycie przez uczniów umiejętności z zakresu umiejętności społecznych mediacji i podstaw prawa; (3) dostrzeganie przez uczniów możliwości rozwiązywania problemów przez swoich rówieśników, skierowanie kwestii spornych do rozwiązania przez szkolnych rówieśniczych mediatorów; (4) promowanie pozytywnych postaw uczniów. Przy założeniu, że działania umożliwiające rozwój instytucji mediacji rówieśniczej przyczynią się do kształtowania postaw w dorosłym życiu, a przez to do rozwoju dojrzałej społeczności obywatelskiej, oczekiwanym

13 Por. Honorowy patronat Rzecznika Praw Dziecka, https://serwisy.gazetaprawna.pl/edukacja/artykuly/1085148,rpd-podstawa-rozwiazywania-konfliktow-w-srodowisku-szkolnym-powinna-byc -mediacja.html (dostęp: 28.07.2021). Por. List Rzecznika Praw Dziecka z dnia 14 listopada 2011 roku, http://sp2.lukow.pl/pliki/zal.pdf (dostęp: 28.07.2021).

Program „Bezpieczny Kraków”, http://bezpieczny.krakow.pl. 
efektem projektu ma być stosowanie mediacji przez dzieci i młodzież w dorosłym życiu oraz rozwiązywanie konfliktów poprzez dialog prowadzący do porozumienia ${ }^{16}$. Jako główny cel przyjęto propagowanie idei sprawiedliwości naprawczej oraz uczenie młodzieży rozwiązywania konfliktów i sporów bez udziału dorosłych. Uczniowie-mediatorzy rozumieją bieżące problemy młodzieży i łatwiej zdobywają uznanie rówieśników.

Wspomniana wcześniej sprawiedliwość naprawcza jest modelem przeciwstawianym sprawiedliwości retrybutywnej, jej główna zaleta to możliwość wysłuchania także tego, który popełnił czyn zabroniony, co wpływa na wzrost poczucia sprawiedliwości i ma ogromne znaczenie dla ładu społecznego. Jak zauważa Jim Consedine, ten zaś „to pożądany stan, w którym musi być miejsce dla sprawcy, który bierze odpowiedzialność za swój czyn, naprawia szkodę ofierze lub społeczności lokalnej, dochodzi do porozumienia stron, a może nawet do pojednania"17. Mediacje rówieśnicze są przykładowymi formami sprawiedliwości naprawczej - w zależności od sytuacji, wagi problemu oraz strategii przyjętej w szkole ${ }^{18}$ jej stosowanie przyczynia się do poprawy atmosfery oraz wspomaga proces nauki. Artykuł 14 Ustawy o nieodpłatnej pomocy prawnej oraz edukacji prawnej (Dz.U. 2015.1255) nakłada na organy administracji publicznej powinność podejmowania działań edukacyjnych zmierzających do zwiększenia świadomości prawnej społeczeństwa. W przepisie położono nacisk na upowszechnianie wiedzy na temat mediacji oraz sposobów pozasądowego rozwiązywania sporów.

Jest to szczególnie istotne w kontekście wyników raportu końcowego Ministerstwa Sprawiedliwości „Diagnoza stanu stosowania mediacji oraz przyczyn zbyt niskiej w stosunku do oczekiwanej popularności mediacji”, będącego rezultatem Programu Operacyjnego „Budowanie potencjału instytucjonalnego i współpraca w obszarze wymiaru sprawiedliwości / Poprawa skuteczności wymiaru sprawiedliwości” realizowanego $\mathrm{w}$ ramach Norweskiego Mechanizmu Finansowego w latach 2009-2014 ${ }^{19}$. Raport wyraźnie wskazuje na niewielką popularność mediacji, a jako jedną z przyczyn

16 Por. Rzecznik Praw Dziecka w liście z dnia 11 października 2011 r., „Kurier Mediacyjny”, wydanie specjalne z okazji Międzynarodowego Dnia Mediacji, Warszawa, 20 października 2011 r., s. 1. J. Consedine, Sprawiedliwość naprawcza. Przywrócenie ładu społecznego, Warszawa 2004, s. 12. Por. R. Raszewska-Skałecka R., M. Szczepkowska, Mediacje w środowisku szkolnym na tle rozważań prawnopsychologicznych - skuteczność i ograniczenia mediacji rówieśniczych, w: Mediacje wspołeczeństwie otwartym, red. M. Tabernacka, R. Raszewska-Skałecka, Wrocław 2012, s. 174-196. http://mediacja.gov.pl/files/doc/rk-mediacje-agrotec-02.09.pdf 
tego stanu podaje niedostateczne uwzględnienie tematyki mediacji w systemie szkolnictwa. W raporcie podkreślono potrzebę podjęcia działań informacyjno-promocyjnych, edukacyjnych i komunikacyjnych, skierowanych do uczniów, nauczycieli i rodziców, które przyczyniłyby się do budowania kultury mediacyjnej i ugruntowania jej pozycji w świadomości społecznej. Działania takie powinno cechować zindywidualizowane podejście do każdej z grup, adekwatne do wieku i poziomu wiedzy adresatów.

\section{Praktyczne aspekty wdrażania mediacji rówieśniczej w szkole}

Tworzenie szkolnych centrów mediacji rówieśniczej może pełnić ważną rolę w socjalizacji prawnej dzieci i młodzieży, promowaniu mediacji, kształtowaniu postaw prospołecznych i podnoszeniu kompetencji interpersonalnych młodzieży. Szkoły powinny zapewniać odpowiednie szkolenia dla zaangażowanych uczniów i nauczycieli, a także zapoznać ich z teorią konfliktu i ideą sprawiedliwości naprawczej. Niezwykle ważnym aspektem jest praca nad rozwijaniem umiejętności umożliwiających efektywną komunikację uczniom-mediatorom. Celem podejmowania działań szkoleniowych jest osiągnięcie stanu, w którym szkoła staje się miejscem przyjaznym dla całej społeczności. Aby być skuteczny, mediacyjny program szkoleniowy powinien mieć charakter ciągły i powinien realizować następujące cele:

- podstawowa edukacja w zakresie prawa;

- kształcenie w zakresie zmiany postaw wobec konfliktu i teoria konfliktu;

- zapoznanie z bezprzemocowymi metodami rozwiązywania sporów;

- rozwijanie umiejętności interpersonalnych;

- kształtowanie umiejętności komunikacyjnych (w tym aktywnego słuchania);

- kształtowanie postawy tolerancji, otwartości i wzajemnego zaufania.

Po ukończeniu szkolenia uczestnicy powinni rozwinąć niezbędne umiejętności miękkie, zrozumieć ideę sprawiedliwości naprawczej i rolę mediacji, która prowadzi do zaspokojenia potrzeb wszystkich stron uczestniczących w konflikcie. W rezultacie tych działań na terenie szkoły powstaje centrum mediacji rówieśniczej, które - jeżeli funkcjonuje prawidłowo - pozwala ograniczyć różnego rodzaju negatywne zachowania wśród młodzieży 
i propaguje rozwiązywanie konfliktów z wykorzystaniem dialogu, w oparciu o empatię i zaufanie. W zakresie warunków organizacyjnych niezbędne jest zagwarantowanie na terenie szkoły właściwego pomieszczenia do przeprowadzania mediacji, które powinno dawać uczniom poczucie bezpieczeństwa i dyskrecji, a ponadto być miejscem neutralnym dla stron konfliktu. Często, o ile szkoła dysponuje takim pomieszczeniem, wyznacza się na ten cel specjalne miejsce - siedzibę, która pozostaje do stałej dyspozycji mediatorów zarówno podczas przeprowadzania sesji mediacyjnych, jak i szkoleń czy warsztatów. Funkcjonujące na terenie danej placówki centrum mediacji rówieśniczej powinno wypracować własne procedury mediacyjne, adekwatne do realiów szkoły. Właściwe wydaje się sporządzenie ogólnodostępnego regulaminu mediacji bądź kodeksu etyki mediatora szkolnego, ponieważ nie tylko wpływa to na zwiększenie rangi projektu i jego estymę, ale też zwiększa wiedzę wszystkich uczniów na temat mediacji i jej przebiegu, a w konsekwencji utrwala ten polubowny sposób rozwiązywania konfliktów w świadomości uczniów, nauczycieli i rodziców.

W niektórych szkołach zapisy dotyczące mediacji i bezprzemocowych form rozwiązywania konfliktów jako podstawowych form mitygowania sporów zostały na stałe wprowadzone do dokumentów statutowych i regulaminów szkolnych ${ }^{20}$. Chcąc wdrożyć mediacje rówieśnicze w szkole, konieczne jest także spełnienie kilku warunków merytorycznych, niezbędne jest, aby cała kadra pedagogiczna została zaznajomiona z metodamiAlternative Dispute Resolutions (dalej: ADR), a w szczególności z zasadami i regułami mediacji, jej podstawowymi założeniami i korzyściami wypływającymi ze stosowania tej metody rozwiązywania konfliktów w szkole. Nauczyciele i uczniowie, którzy będą czynnie zaangażowani w realizację projektu tworzenia centrum mediacji rówieśniczej w szkole, powinni odbyć - jak już wspomniano wcześniej - właściwe szkolenia, które pozwolą im poszerzyć wiedzę i zdobyć doświadczenie w zakresie właściwego prowadzenia sesji mediacyjnych i dialogu z rówieśnikami w konflikcie. Takie szkolenia nie tylko kształcą, ale podnoszą również prestiż projektu. Ponadto stanowią element, który dodatkowo może zachęcić uczniów do aktywnego udziału w projekcie i kontynuowania tych praktyk w kolejnym roku szkolnym. Po odbyciu szkoleń

20 Przykładem dobrej praktyki wdrażania elementów mediacji w szkole może być Gimnazjum i Liceum im. Stefana Batorego w Warszawie. W paragrafie 15 ust. 5 statutu szkoły można znaleźć informację, że „uczniowie mają prawo powołać Rzecznika Praw Ucznia - mediatora w razie sytuacji konfliktowych". 
uczniowie-mediatorzy dysponują wiedzą i praktycznymi umiejętnościami, które niejednokrotnie mogą okazać się przydatne także w ich życiu prywatnym lub też - już w dorosłym życiu - zawodowym. Zdecydowana większość sytuacji konfliktowych, do których dochodzi na terenie szkoły, nadaje się do mediacji rówieśniczej. Należy wyszczególnić kilka czynników, na podstawie których dany konflikt może zostać rozwiązany z zastosowaniem mediacji rówieśniczej. Po pierwsze, konflikt powinien dotyczyć uczniów - trudno wyobrazić sobie sytuację, w której mediacji rówieśniczej zostaje poddana sprawa niemająca związku z realiami szkolnymi i niedotycząca w żadnym stopniu uczniów określonej placówki oświatowej. Należy jednak zaznaczyć, że uczestnikami mediacji rówieśniczej - na różnych warunkach, w tym superwizyjnych - mogą być także inne osoby, na przykład nauczyciele czy rodzice uczniów. Kolejnym kryterium jest pewność, że pomiędzy skonfliktowanymi uczniami uda się zachować równowagę i żadna ze stron nie będzie w uprzywilejowanej pozycji - nikt nie zdominuje rozmowy. W tym kontekście bardzo istotna jest rola nauczyciela-opiekuna i mediatora rówieśniczego, którzy powinni bezpośrednio wpływać na strony podczas spotkania mediacyjnego, dbając o ich komfort i poczucie bezpieczeństwa.

Sposób wprowadzenia mediacji rówieśniczej w placówce ma kluczowe znaczenie dla powodzenia całego przedsięwzięcia. To już od pierwszych czynności podejmowanych w tym zakresie zależy bowiem, czy nauczyciele, rodzice i uczniowie potraktują projekt $\mathrm{z}$ niezbędną powagą, entuzjazmem i zaangażowaniem. Przed przystąpieniem do realizacji projektu w szkole należy przeprowadzić serię spotkań informacyjnych z gronem pedagogicznym i dyrekcją, w trakcie których zaprezentowane zostaną podstawowe informacje na temat mediacji i informacje na temat poszczególnych etapów projektu. Na tym etapie należy rozwiać wszelkie wątpliwości związane z koniecznym zaangażowaniem nauczycieli i uczniów w realizowany projekt, należy również wskazać wszelkie korzyści związane ze stosowaniem mediacji w danej placówce oświatowej - odwołując się wprost do realiów i codziennych problemów szkolnej społeczności. Spotkania mają na celu nie tylko podnosić wiedzę kadry na temat metod ADR, ale także uzyskać ich zgodę na utworzenie centrum mediacji rówieśniczej w danej placówce. Kolejnym etapem jest wybór lub wyznaczenie osób odpowiedzialnych za prowadzenie projektu w szkole - nauczycieli koordynatorów. To oni będą odpowiedzialni za przeprowadzenie wstępnych sesji informacyjnych z rodzicami i uczniami, za 
prezentację podstawowych metod i szczegółowych założeń projektu. Kolejnym niezwykle ważnym dla całego przedsięwzięcia etapem jest wyłonienie z grona uczniów mediatorów rówieśniczych. Po przeprowadzeniu sesji informacyjnych i wytypowaniu kandydatów na uczniów-mediatorów należy niezwłocznie przeprowadzić stosowne szkolenia z zakresu mediacji. Szkolenia powinny zostać skierowane do nauczycieli i uczniów bezpośrednio zaangażowanych w pracę nad projektem szkolnego centrum mediacji rówieśniczej, ale możliwe jest także zorganizowanie uproszczonych szkoleń o charakterze informacyjnym dla całej społeczności szkolnej. Niezbędne jest również stworzenie regulaminu mediacji szkolnych i uwzględnienie go w dokumentach statutowych danej szkoły - obowiązującego wszystkich uczniów i nauczycieli - czyniąc tym samym mediację oficjalną metodą wychowawczą stosowaną w danej placówce oświatowej. W rezultacie wspominanych powyżej działań możliwe stanie się rozpoczęcie usystematyzowanych działań z zakresu mediacji rówieśniczej, które umożliwią kontynuowanie projektu w przyszłości i adekwatną superwizję pracy mediatorów rówieśniczych.

\section{Dobre praktyki w zakresie wdrażania mediacji rówieśniczej w placówkach oświatowych}

Instytucja mediacji rówieśniczych z roku na rok zyskuje coraz większą popularność i staje się tematem nie tylko dyskutowanym w gronie pedagogów, ale również coraz częściej faktycznie wdrażanym w polskich szkołach. W październiku 2016 roku Rzecznik Praw Dziecka powołał Zespół ds. opracowania standardów mediacji szkolnej i rówieśniczej, w którego skład wchodzili wybitni specjaliści z zakresu mediacji, mediacji rówieśniczej i pedagogiki. Zadaniem zespołu było nie tylko przygotowanie standardów mediacji szkolnej i rówieśniczej, ale także opracowanie m.in. Kodeksu Etyki Mediatora Rówieśniczego i Kodeksu Etyki Mediatora Szkolnego ${ }^{21}$. Pozwala to szkołom chcącym wdrożyć program mediacji rówieśniczych na podjęcie świadomych i ukierunkowanych działań zmierzających do edukacji dzieci i młodzieży w zakresie podstaw prawa i ADR. W tym miejscu warto przybliżyć kilka projektów i inicjatyw związanych z implementacją i popularyzacją mediacji rówieśniczej, które zostały zrealizowane w polskich szkołach w ciągu kilku ostatnich lat. Jednym z największych przedsięwzięć tego typu był realizowany

21 http://brpd.gov.pl/aktualnosci/rpd-przygotuje-standardy-mediacji-szkolnej-i-rowiesniczej 
przez Regionalny Ośrodek Pomocy Społecznej Województwa Małopolskiego projekt „Mediacja Rówieśnicza”, prowadzony w palcówkach opiekuńczo-wychowawczych w 2009 roku. Projekt został wdrożony w 15 placówkach, wzięło w nim udział 33 wychowawców i 114 wychowanków. Celem projektu było zwiększenie umiejętności komunikacyjnych uczestników, pogłębienie ich wiedzy w zakresie polubownego rozwiązywania sporów i kształtowanie tolerancyjnej postawy wychowanków wspomnianych ośrodków ${ }^{22}$. W latach 2018-2020 w Krakowie realizowano program poprawy bezpieczeństwa w mieście, w ramach którego w 28 szkołach na terenie Krakowa zrealizowano projekt szkoleniowy dla mediatorów rówieśniczych „Szkoła Młodych Mediatorów”. Projekt poprzedzony był również serią seminariów dla dyrektorów krakowskich szkół, w trakcie których uczestniczyli oni w wykładach i praktycznych warsztatach dotyczących mediacji rówieśniczej ${ }^{23}$. Inną znaczącą inicjatywą dotyczącą mediacji rówieśniczej był podjęty w 2019 roku przez Rzecznika Praw Obywatelskich, Rzecznika Praw Dziecka oraz Polskie Centrum Mediacji w Lublinie projekt „Mediacja rówieśnicza w szkole metodą przeciwdziałania agresji i niedostosowaniu społecznemu", do którego przystąpiło 11 gimnazjów z województwa lubelskiego. Projekt miał na celu przeszkolenie nauczycieli i uczniów w zakresie mediacji i możliwości jej zastosowania w szkołach, a w rezultacie utworzenie w tych placówkach działających stale centrów mediacji rówieśniczej, które współpracowałyby z licznymi podmiotami zajmującymi się prawem, edukacją i interwencją kryzysową (sądy, kuratoria, $\mathrm{PCM})^{24}$. Oprócz większych programów realizowanych przez lokalne ośrodki mediacyjne i podmioty z nimi współpracujące warto także wspomnieć kilka przykładów samodzielnych placówek szkolnych, które podjęły próbę wdrożenia mediacji rówieśniczej, jak choćby Gimnazjum nr 21 w Gdańsku, w którym w 2014 roku powołano Centrum Mediacji Szkolnej i Rówieśniczej, gdzie pod nadzorem szkolnego pedagoga-mediatora nadal (pomimo reformy edukacji) działa grupa szkolnych mediatorów rówieśniczych, którzy na co dzień rozwiązują konflikty, do których dochodzi w szkole ${ }^{25}$. Warto też wspomnieć

22

23

http://www.rops.krakow.pl/lewa/dziecko-i-rodzina-1o/projekt-mediacje-rowiesnicze-6o.html. http://bezpieczny.krakow.pl/ii-cykl-seminariow-pn-bezpieczna-szkola-25-26-10-2019-r/ oraz http://bezpieczny.krakow.pl/konferencja-mediacja-rowiesnicza-szansa-na-lepsza-przyszlosc-1012-2019-r/.

24 https://www.rpo.gov.pl/pl/content/program-mediacja-rowiesnicza-w-szkole-metodaprzeciwdzialania-agresji-i-niedostosowaniu-spolecznemu-mlodziezy.

http://www.gimnazjum21.gda.pl/centrum-mediacji-szkolnej-i-rowiesniczej-4507/ aktualnosci-cmsir-4509. 
o III Liceum Ogólnokształcącym w Ostrowie Wielkopolskim, które w marcu 2017 roku również powołało do życia Szkolne Centrum Mediacji ${ }^{26}$, stając się tym samym jedną z niewielu szkół średnich w Polsce, korzystających z tego sposobu rozwiązywania sporów - zazwyczaj na wdrożenie programu decydują się szkoły podstawowe i gimnazja.

\section{Skuteczność programów mediacji rówieśniczej}

Mimo że w polskich szkołach coraz częściej wdraża się mediacje rówieśnicze, wciąż nie powstało zbyt wiele opracowań dotyczących efektywności takich programów. W związku z tym na szczególną uwagę zasługują badania przeprowadzone przez prof. Agnieszkę Lewicką-Zelent, która przeanalizowała wpływ wdrożenia mediacji rówieśniczej w szkole (rok szkolny 2008/2009) na klimat placówki oświatowej ${ }^{27}$ i zasoby osobiste (rozumiane jako cechy, postawy i kompetencje mediacyjne) uczniów szkół gimnazjalnych w Rykach i Lublinie ${ }^{28}$. W wyniku przeprowadzonych badań ustalono, że - zarówno z perspektywy uczniów, jak i nauczycieli - wdrożenie mediacji rówieśniczej w szkole miało pozytywny wpływ na panujący w niej klimat i zasoby osobiste uczniów. Powyższe rezultaty świadczą zatem o zauważalnej skuteczności programów mediacji rówieśniczej i powinny stanowić argument przemawiający za ich popularyzacją w polskich szkołach - przy uwzględnieniu reform oświatowych.

\section{Podsumowanie}

Implementacja instytucji mediacji rówieśniczej w szkołach może w znacznym stopniu przyczynić się do socjalizacji prawnej dzieci i młodzieży oraz popularyzacji alternatywnych metod rozwiązywania sporów. Mediacja rówieśnicza sprzyja kształtowaniu postaw prospołecznych, zdobywaniu wiedzy na temat podstaw prawa i rozwijaniu umiejętności interpersonalnych uczniów-mediatorów. Oficjalnie umocowane w szkolnych statutach i regulaminach centrum mediacji rówieśniczej może skutkować zwiększeniem

26 http://brpd.gov.pl/aktualnosci/w-wielkopolsce-o-prawach-dziecka-i-mediacji-rowiesniczej

27 Por. A. Lewicka-Zelent, Klimat szkół gimnazjalnych. Diagnoza weryfikacyjna programu „Mediacja w szkole", Wydawnictwo Naukowe SCRIPTORIUM, Opole 2014.

28 Por. A. Lewicka-Zelent, Analiza zasobów osobistych uczestników szkolnego warsztatu mediacyjnego, Wydawnictwo Naukowe SCRIPTORIUM, Opole 2014. 
świadomości uczniów w zakresie polubownych form rozwiązywania konfliktów, a w efekcie może mieć pozytywny wpływ na atmosferę panującą w szkole - uczniom będzie zależało na budowaniu dobrych relacji, wzajemnym zrozumieniu i zaufaniu. Oddanie sprawiedliwości w ręce uczniów sprawia, że wzrasta wśród nich poczucie odpowiedzialności za popełniane czyny, a możliwość zastosowania superwizji jest gwarantem bezpieczeństwa i szansą na ciągłe ulepszanie i podnoszenie umiejętności w zakresie technik mediacyjnych. Biorąc pod uwagę nowe zagrożenia i realia panujące we współczesnej szkole, należy zdecydowanie opowiedzieć się za wprowadzeniem do placówek oświatowych programów edukacyjnych promujących mediację rówieśniczą - z uwzględnieniem nowych technologii i zagrożeń z tym związanych. Wypracowywane w tej materii przez ekspertów - Rzecznika Praw Dziecka i Rzecznika Praw Obywatelskich - najlepsze praktyki i standardy mogą przyczynić się do uspójnienia coraz częściej stosowanych w polskich szkołach praktyk mediacji rówieśniczej.

\section{Bibliografia}

1. Adler R. B., Rosenfeld L. B., Proctor II R.F., Relacje interpersonalne - proces porozumiewania się, Rebis, Poznań 2011.

2. Borkowska A., Szymańska J., Witkowska M., Przeciwdziatanie agresji i przemocy w szkole. Poradnik dla nauczycieli, Warszawa 2012, http://www.ore.edu.pl.

3. Borucka-Arctowa M., Skąpska G., Teoretyczne problemy socjalizacjiprawnej, w: Socjalizacja prawna, red. M. Borucka-Arctowa, Ch. Kourilsky, Warszawa 1993, s. 11-27.

4. Consedine J., Sprawiedliwość naprawcza. Przywrócenie tadu społecznego, Warszawa 2004.

5. Czapska J., Szeląg-Dylwski M., Innowacja przez prawo, czyli rzecz o mediacji i zaufaniu, w: Mediacje w prawie, red. J. Czapska, M. Szeląg-Dylewski, Kraków 2014.

6. Czapski M., Mediacja w sporach akademickich, w: Mediacje - teoria ipraktyka, red. E. Gmurzyńska, R. Morek, Warszawa 2014, s. 417-433.

7. Godyla B., Socjalizacyjny wptyw szkoty na rozwój spoteczny dziecka, „EduX.pl”, http://www.edukacja.edux.pl/p-617-socjalizacyjny-wplyw-szkoly-na-rozwoj.php.

8. Klaus W., Wykorzystanie sprawiedliwości naprawczej w zapobieganiu przemocy rówieśniczej w szkole, w: Mediacja, red. L. Mazowiecka, Warszawa 2009, s. 339.

9. Lewicka-Zelent A., Klimat szkót gimnazjalnych. Diagnoza weryfikacyjna programu „Mediacja w szkole”, Wydawnictwo Naukowe SCRIPTORIUM, Opole 2014. 
10. Lewicka-Zelent A., Analiza zasobów osobistych uczestników szkolnego warsztatu mediacyjnego, Wydawnictwo Naukowe SCRIPTORIUM, Opole 2014.

11. Piquero A.R., Fagan J., Mulvey P.E., Steinberg L., Odgers C., Developmental Trajectories of Legal Socialization Among Serious Adolescent Offenders, „The Journal of Criminal Law and Criminology" (2005) no. 96 (1), s. 267-298.

12. R. Raszewska-Skałecka, Mediacje rówieśnicze jako instrument przeciwdziałania agresji i rozwiązywania konfliktów w szkole, w: Mediacje ponad podziałami, red. M. Tabernacka, Wrocław 2013, p. 71-83 (e-Monografie, 41).

13. Raszewska-Skałecka R., Szczepkowska M., Mediacje w środowisku szkolnym na tle rozważań prawnopsychologicznych - skuteczność i ograniczenia mediacji rówieśniczych, w: Mediacje w społeczeństwie otwartym, red. M. Tabernacka, R. Raszewska-Skałecka, Wrocław 2012, s. 174-196.

14. Surzykiewicz J., Agresja iprzemoc w szkole. Uwarunkowania socjoekologiczne, Warszawa 2000.

15. Wojcieszczak A., Mediacja rówieśnicza jako metoda ksztattowania postaw prospotecznych i przeciwdziatania agresji wśród dzieci i młodzieży, w: Bezpieczne miasto - w poszukiwaniu wiedzy przydatnej praktykom, red. J. Czapska, P. Mączyński, K. Struzińska, Kraków 2017, s. 221-236.

16. Wojtanowicz K., Mediacje rówieśnicze jako metoda wychowawcza, „Studia Socialia Cracoviensia" 8 (2016) nr 2 (15), s. 145-155.

17. Ustawa $z$ dnia 5 sierpnia 2015 r. o nieodpłatnej pomocy prawnej oraz edukacji prawnej (Dz.U. z 2015 poz. 1255)

\section{Źródła internetowe}

18. Program poprawy bezpieczeństwa w mieście Kraków. „Bezpieczny Kraków”, http:// bezpieczny.krakow.pl

19. Program Rzecznika Praw Obywatelskich „Mediacja rówieśnicza w szkole - metoda przeciwdziałania agresji i niedostosowaniu społecznemu młodzieży”, https:// www.rpo.gov.pl/pl/content/program-mediacja-rowiesnicza-w-szkole-metodaprzeciwdzialania-agresji-i-niedostosowaniu-spolecznemu-mlodziezy

20. Standardy mediacji rówieśniczej i szkolnej RPD, http://brpd.gov.pl/sites/default/ files/standardy_mediacji_rowiesniczej_i_szkolnej_w_szkolach_o.pdf. 